\title{
SUPPLEMENTATION OF INSTANT NOODLES BY COLLAGEN HYDROLYSATE AS A FUNCTIONAL FOOD
}

(Received: 8.12. 2020)

\author{
By \\ Amira M. A. Abd El-Salam and M. F. S. A. Kodous \\ Food Technology Research Institute, Agricultural Research Center, Giza, Egypt.
}

\begin{abstract}
Collagen is responsible for the elasticity and freshness of the skin giving it the necessary softness and wrinkles fighting and preventing the early appearance of its marks on the skin. It also prevents the occurrence of arthritis and bone pain and strengthens muscles. The progress in age causes low natural collagen production by the body. Therefore it is useful to compensate this decrease from another sources, preferably a natural source. In this study, instant noodles were produced from hard wheat or corn flour containing collagen hydrolysate extracted from chicken feet as a functional food by three levels of $\mathrm{pH}$ (4.0, 6.5 and 9.0). The best protein content of collagen hydrolysate was obtained from treatment by $\mathrm{pH} 4.0$, thus this treatment was used in supplementation of instant noodles at levels of 10, 20 and 30\%. Chemical composition, amino acids content, sensory evaluation, shear force and cooking quality of instant noodle blends were improved. The blends of instant noodles supplemented with collagen hydrolysate had a high protein content which ranged from 20.13 to $34.95 \%$ for hard wheat blends and from 25.54 to $33.30 \%$ for yellow corn blends. Regarding amino acids content, chicken feet collagen had the highest value of threonine, alanine, glycine, proline, hydroxylysine and hydroxyproline compared to hard wheat and yellow corn flour. Regarding the percentages of the recommended dietary allowances (RDA \%) provided from $100 \mathrm{~g}$ of different instant noodles for age of $31-50$ years old, the results showed that all values of RDA \% for protein was high in instant noodles produced from hard wheat flour which ranged from 35.95 to $62.41 \%$ for males and ranged from 43.76 to $75.98 \%$ for females compared to the control sample which showed RDA \% value of 22.61 and $27.52 \%$ for males and females, respectively. Also, the results showed that all values of RDA \% for protein was high in instant noodles produced from yellow corn flour which ranged from 32.02 to $59.46 \%$ for males and ranged from 38.98 to $72.39 \%$ for females compared to the control sample which showed RDA \% value of 18.43 and $22.43 \%$ for males and females, respectively. The results showed that the product of yellow corn flour instant noodles can be used as a functional food for patients suffering from celiac disease.
\end{abstract}

Key words: instant noodles, chicken feet, collagen hydrolysate, amino acids and celiac disease.

\section{INTRODUCTION}

Instant noodles gain popularity due to their ready-to-eat convenience, cost competitiveness, availability of various products with different taste and texture, beneficial nutrition, and long shelf life. Globally, the consumption of wheat instant noodles is second to bread (Shin and Kim, 2003). With nearly $40 \%$ of wheat being processed into instant noodles in Asia (Hou, 2001). Recently, the consumption of instant noodles has been increasing in the fastest pace in cereal foods (Choy et al., 2010).

Chicken feet contain a large amount of protein, essential minerals and collagen which is the major component of protein (Polian, 2012).
Chicken feet utilization can be further enhanced by processing it into useful products like readyto-use chicken soup mixes, gelatin (Taha et al., 2015 and Jayathilakan et al., 2010)). Chicken feet collagen is extracted for various applications in food and pharmaceutical industries using acidic, alkaline, thermal and enzymatic hydrolysis methods (Wei et al., 2013 and Delgado et al., 2017)). Study of the isolation and characteristic of collagen from chicken feet can increase the value-added potential of this byproduct and its utilization in medical, cosmetic as well as in food application (Hashim et al., 2014). The collagen protein substance is naturally occurring in the human body, but the 
problem occurs with age progress, the body's ability to produce collagen, which leads to changes in flexibility and increases in the inflammatory pain and arthritis, so it is recommended to take collagen from another sources. The most popular and used is the gelatin of mammals (pigs and cattle) that are subjected to greater restrictions and skepticism among consumers, by socio-cultural and health concerns (Karim and Bhat, 2009). Collagen hydrolysate $(\mathrm{CH})$ has long been used in pharmaceuticals and foods in many countries and regions, such as United States, Europe, China and Japan. Approved as Generally Recognized As Safe (GRAS), the safety of $\mathrm{CH}$ has been affirmed by the Food and Drug Administration (FDA) Center for Food Safety and Nutrition. The bioavailability and absorption of $\mathrm{CH}$ have also been widely studied. It has been reported that $\mathrm{CH}$ is more easily absorbed and has higher bioavailability than gelatin (Oesser et al., 1999 and Song et al., 2017). Ohara et al., (2010), Hatanaka et al., 2014 and Hongdong and Bo, $2017)$ reported that Collagen hydrolysate $(\mathrm{CH})$ has many beneficial effects include antioxidant, anti aging, anti osteoporotic , anti osteoarthritis, anti-inflammatory, anti tumor, anti hypertensive, anti atherosclerotic, anti obesity and hypoglycemic effects.

The development of new food products has been explored, through the discovery of new sources of food or the reuse of by-products or wastes. For this, nutritional and sensory aspects should be taken into account, so they could supply some vitamin or minerals without rejecting the product by the consumers. In this context, there are the so-called functional foods (Rodrigues et al., 2011).

Celiac disease is a chronic disease of the gastrointestinal system, in which characteristics atrophy of the small intestinal mucosa occurs in genetically predisposed people in response to the presence of gluten in food. It is a continuous intolerance of gluten, gliadin and responsive prolamins that are present in wheat, rye and barley (Amin et al., 2002). Functional food is food similar in appearance to conventional food, which is consumed as a part of the usual diet and has demonstrated physiological benefit and/or reduces the risk of chronic disease beyond basic nutritional functions (Mohamed et al., 2004).

Chicken feet can be used as an alternative source of collagen for the development of new products. In this sense, the aim of this study was the production of noodles using hard wheat flour or yellow corn flour supplemented with collagen hydrolysate extracted from chicken feet for fortification of noodles by protein and calcium, also to produce free gluten noodles by using yellow corn flour as a functional food.

\section{MATERIALS AND METHODS \\ 2.1.Materials}

Hard wheat flour $(72 \%$ ext.) was obtained from South Cairo Mills Company, Giza, Egypt.

Yellow corn flour was obtained from Food Technology Research Institute, Agricultural Research Center, Giza, Egypt.

Chicken feet were obtained from the local market at Giza, Egypt. Immediately after slaughtering, the samples were transported using an ice box to the laboratory of Meat and Fish Technology, Food Technology Research Institute Salt was obtained from local market of Giza, Egypt.

\subsection{Methods}

\subsubsection{Preparation of chicken feet collagen hydrolysate}

1- Chicken feet were cleaned, washed thoroughly and soaked in boiling water for 3 minutes and the surface yellow membranes on the feet were peeled according to the method of Yang et al. (2009) with some modifications by Wei et al. (2013). Chicken feet were immersed in a mixture of $0.25 \mathrm{~mol} / \mathrm{l}$ $\mathrm{NaOH}$ and $1 \%$ hydrogen peroxide $(\mathrm{v} / \mathrm{v})$ by ratio of 1:7 (w/v) and held at room temperature for 40 minutes. The chicken feet samples were drained, and squeezed by hand. The alkali pre-treated chicken feet samples were then washed under running tap water for $40 \mathrm{~min}$ and drained, and subsequently soaked in $0.2 \%$ sulphuric acid $(1: 7, \mathrm{w} / \mathrm{v})$ for 40 minutes. The liquid was drained and the samples were flushed with tap water. Finally, the chicken feet samples were soaked in 0.3 $\mathrm{mol} / \mathrm{L}$ acetic acid $(1: 7, \mathrm{w} / \mathrm{v})$ for $40 \mathrm{~min}$ and flushed with tap water to remove the remaining acid. The chicken feet samples were then drained and weighed.

2-The chicken feet were cooked at three deferent degrees of $\mathrm{pH}(4.0,6.5$ and 9.0) under pressure in an autoclave at $121^{\circ} \mathrm{C}$ for 3 hours.

3-Cooked chicken feet were separated and the remained liquid was concentrated

4 -The bones were removed from cooked mass to obtain the deboned feet meat

5 -The deboned meat of chicken feet was minced and added to the concentrated liquid. 
The mixture was blended to obtain slurry.

6 - The obtained ground slurry was dried at 50 ${ }^{\circ} \mathrm{C}$ for 24 hour

7- The chicken feet collagen hydrolysate was grinded and dried, then the product was stored at $-20^{\circ} \mathrm{C}$ until use .

The yield (\%) was calculated as (dried collagen hydrolysate $(\mathrm{g}) /$ Chicken feet $(\mathrm{g})) \times$ 100 , according to the method described by Wei et al. (2013).

\subsubsection{Preparation of instant noodles}

Instant noodles was prepared in laboratory using hard wheat flour $72 \%$ ext. or yellow corn flour with different levels of chicken feet collagen hydrolysate (10, 20 and 30\%) according to the method described by Park et al. (2004).

The formulas are shown in Table (1). One kilogram of each dough blends of the tested combinations of raw materials was mixed with the required amount of water. After the complete addition of water, mixing was continued for 8 min. The premixed dough was placed in the vacuum mixer of the Demaco molder (Demaco, De francis machine corporation Germany) under condition of $21 \mathrm{rpm}, 25^{\circ} \mathrm{C}$. An extension tube was added to ensure uniform hydration of the instant noodles dough prior to extrusion. The instant noodles was steamed for 3 to 4 min.

\subsubsection{Minerals analysis}

Calcium $(\mathrm{Ca})$ magnesium $(\mathrm{Mg})$ and iron $(\mathrm{Fe})$, were determined using a Pye Unicom SP 19000 atomic absorption spectroscopy technology as described by A.O.A.C. (2005).

Determination of total amino acids was carried out as described in the A.O.A.C. (2005).

Tryptophan was analyzed in triplicate by HPLC, according to the method of Slump et al. (1991).

Total volatile nitrogen (TVN) was determined according to the method published by Winton and Winton (1958).

The $\mathrm{pH}$ value was determined according to Aitken et al. (1962).

Thiobarbituric acid (TBA) value was determined as described by Egan et al. (1981).

Water activity value of the dried samples mixtures was measured using Rotronic Hygrolab 3CH-8303, Switzerland as mentioned by Cadden (1988).

Rehydration ratio was performed according to the methods of Krokida and Marinos-Kouris (2003).

\subsubsection{Cooking quality of instant noodles}

Weight increase \% and volume increase $\%$ of instant noodles were determined according to the method described by Dexter et al. (1990) by cooking $25 \mathrm{~g}$ of each sample in one litter of

Table (1): Formula of instant noodles blends.

\begin{tabular}{|c|c|c|c|c|c|}
\hline \multirow[t]{2}{*}{ Ingredients } & \multicolumn{5}{|c|}{ Instant noodles(g) } \\
\hline & Control 1 & Blend 1 & Blend 2 & Blend 3 & Blend 4 \\
\hline Hard wheat flour (HWF) & 1000 & 900 & 800 & 700 & 600 \\
\hline \multirow[t]{2}{*}{ Chicken feet collagen hydrolysate (CFCH) } & - & 100 & 200 & 300 & 400 \\
\hline & Control 2 & Blend 5 & Blend 6 & Blend 7 & Blend 8 \\
\hline Yellow corn flour(YCF) & 1000 & 900 & 800 & 700 & 600 \\
\hline Chicken feet collagen hydrolysate (CFCH) & - & 100 & 200 & 300 & 400 \\
\hline Salt $(\mathrm{gm})$ & \multicolumn{5}{|c|}{ All 10} \\
\hline Water $(\mathrm{ml})$ & \multicolumn{5}{|c|}{$330-360$} \\
\hline Control (1) $=100 \%$ HWF & \multicolumn{5}{|c|}{ Control $(2)=100 \%$ YCF. } \\
\hline Blend $(\mathbf{1})=90 \% \mathrm{HWF}+10 \% \mathrm{CFCH}$. & \multicolumn{5}{|c|}{ Blend $(2)=80 \% \mathrm{HWF}+20 \% \mathrm{CFCH}$} \\
\hline Blend $(\mathbf{3})=70 \% \mathrm{HWF}+30 \% \mathrm{CFCH}$ & \multicolumn{5}{|c|}{ Blend (4) $=60 \% \mathrm{HWF}+40 \% \mathrm{CFCH}$} \\
\hline Blend (5) = 90\% YCF +10\% CFCH & \multicolumn{5}{|c|}{ Blend $(6)=80 \% \mathrm{YCF}+20 \% \mathrm{CFCH}$} \\
\hline Blend $(7)=70 \% \mathrm{YCF}+30 \% \mathrm{CFCH}$ & \multicolumn{5}{|c|}{ Blend $(8)=60 \% \mathrm{YCF}+40 \% \mathrm{CFCH}$. } \\
\hline
\end{tabular}

\subsubsection{Chemical analysis}

Moisture, protein, ash, crude fiber and crude fat were determined according to the methods described in A.O.A.C. (2005), nitrogen free extract was determined by difference.

Total calories was calculated according to FAO/ WHO (1973) as follows:

$\mathrm{E}=4 \mathrm{X}$ (nitrogen free extract $\%+$ protein $\%)+$ 9X (fat \%) Where: $\mathrm{E}=$ Energy as kcal per $100 \mathrm{gm}$. boiling water for 5 min., the samples were washed and allowed to drain for $2 \mathrm{~min}$.

Weight increase $\%=[($ Weight of cooked sample- weight of uncooked sample) / (weight of uncooked sample)] X100.

Volume increase $\%=[($ volume of cooked sample-volume of uncooked sample) / (volume of uncooked sample)] X100.

Total soluble solids of cooking liquid were determined as cooking loss \% according to the 
method of Walash and Cilles (1971). The residue weight was calculated as a percentage based on the uncooked product weight as follows:

Cooking loss $\%=$ (weight of residues in cooking water/weight of uncooked sample) X100.

\subsubsection{Sensory evaluation of instant noodles}

The cooked instant noodles were evaluated for their sensory characteristics by ten panelists from the staff of bread and pastry, Food Technology Research Institute, Agricultural Research Center, Giza, Egypt, according to the method of Abd El-Salam (2005).

\subsubsection{Statistical analysis:}

Statistically analyzed using analysis of variance and least significant differences (L.S.D) according to method of Snedecor and Cochran (1980).

\section{RESULTS AND DISCUSSION \\ 3.1. Effect of different $\mathrm{pH}$ degrees on the chemical composition of extracted collagen hydrolysate:}

Collagen hydrolysate was extracted from chicken feet using cooking at three deferent degrees of $\mathrm{pH}(4.0,6.5$ and 9.0) in an autoclave at $121^{\circ} \mathrm{C}$ for 3 hours and the chemical composition of the tested samples is shown in Table (2).

The obtained results pointed that significant differences were found between all treatments $(\mathrm{pH} 4.0,6.5$ and 9.0) for moisture ,protein and ash contents, while no-significant differences were observed for content of lipid and minerals (calcium, magnesium and iron), where extracted collagen hydrolysate at $\mathrm{pH} 4.0$ showed the highest content of protein and the lowest content for moisture, ash, lipid and minerals except iron content when compared with extracted collagen hydrolysate at $\mathrm{pH} 6.5$ and 9.0. These results agree with earlier studies by Wei et al., (2013) and Yang et al., (2009). They found that extracted collagen hydrolysate from Tilapia skin fish at $\mathrm{pH} 4.0$ showed higher content of protein than at $\mathrm{pH} 6.5$ and 9.0.

\subsection{Effect of different $\mathrm{pH}$ degrees on amino} acid contents of collagen hydrolysate

The effect of different $\mathrm{pH}$ degrees on amino acid contents of collagen hydrolysate was studied and the obtained results are shown in Table (3).

The results presented in Table (3), indicated that the collagen hydrolysate produced at $\mathrm{pH}$ degree of 4.0 was high in proline and hydroxyproline contents, which known to be very important for producing glucosamine in the human body in the presence of ascorbic acid (Morimura et al., 2002). On the other hand, the same results showed that values of hydroxyproline, proline, glycine, aspartic, serine, valine, lysine, hydroxylysine, arginine, and methionine contents were higher at $\mathrm{pH} 4.0$ compared with $\mathrm{pH} 6.5$ and 9.0. This may be due to acid condition of $\mathrm{pH} 4.0$ which influenced positively on the hydrolyzation degree (Morimura et al., 2002).

\subsection{Effect of different pH degrees on chemical quality attributes of collagen hydrolysate}

The effect of different $\mathrm{pH}$ degrees on chemical quality attributes of collagen hydrolysate was studied and the obtained results are shown in Table (4).

The presented data in Table (4) showed that the collagen hydrolysate produced at $\mathrm{pH} 4.0$ contained significantly the highest level of TVN $(8.75 \mathrm{mg} / 100 \mathrm{mg})$ followed by the collagen hydrolysate produced at $\mathrm{pH} 9.0$ and 6.5 which scored 6.80 and $4.35 \mathrm{mg} / 100 \mathrm{mg}$, respectively. This may be due to protein content was higher in the hydrolysed collagen produced at $\mathrm{pH} 4.0$ compared with the hydrolysed collagen produced at $\mathrm{pH} 9.0$ and 6.5 , respectively, as previously indicated in Table (2), and may be due also to the direct relationship between protein content and TVN, during drying period, since microbial and enzyme activities led to disintegration of protein components, so with increasing protein content in sample the level of TVN increased (Sanchez- Alouso et al., 2008).

From the same Table (4), the data showed also that there was no-significant difference of TBA for collagen hydrolysate produced at deferent degree of $\mathrm{pH}$ (4.0, 6.5 and 9.0), although TBA level was the highest in collagen hydrolysate produced at $\mathrm{pH} 9.0$ followed by $\mathrm{pH}$ 6.4 and 4.0 , respectively.

The data in Table (4) showed also that the collagen hydrolysate produced at $\mathrm{pH} 4.0$ recorded the highest value of $\mathrm{pH}$ followed by the collagen hydrolysate produced at $\mathrm{pH} 9.0$ and 6.5. These results confirmed the higher TVN content of the collagen hydrolysate produced at $\mathrm{pH} 4.0$ than the collagen hydrolysate produced at $\mathrm{pH} 9.0$ and 6.5 as there is a direct relationship between TVN content and $\mathrm{pH}$ value (SanchezAlouso et al., 2008). 
Table (2): Effect of different pH degrees on the chemical composition of extracted collagen hydrolysate from chicken feet (on dry weight basis).

\begin{tabular}{|l|c|c|c|c|}
\hline \multirow{2}{*}{ Component } & \multicolumn{2}{|c|}{ Different degree of pH } & \multirow{2}{*}{ LSD } \\
\cline { 2 - 4 } & PH 4.00 & pH 6.50 & pH 9.00 & \\
\hline Moisture (\%) & $7.13^{\mathrm{c}} \pm 0.9$ & $8.19^{\mathrm{a}} \pm 0.85$ & $7.97^{\mathrm{b}} \pm 0.95$ & 1.280 \\
\hline Protien (\%) & $86.96^{\mathrm{a}} \pm 1.12$ & $83.20^{\mathrm{c}} \pm 1.06$ & $84.40^{\mathrm{b}} \pm 0.98$ & 1.416 \\
\hline Lipd (\%) & $0.93^{\mathrm{a}} \pm 0.20$ & $1.39^{\mathrm{a}} \pm 0.20$ & $1.24^{\mathrm{a}} \pm 0.10$ & 0.137 \\
\hline Ash (\%) & $5.08^{\mathrm{c}} \pm 0.53$ & $7.23^{\mathrm{a}} \pm 0.65$ & $6.12^{\mathrm{b}} \pm 0.81$ & 0.913 \\
\hline Calcium (Ca)(mg/100g) & $88.00^{\mathrm{a}} \pm 0.95$ & $91.30^{\mathrm{a}} \pm 1.13$ & $90.80^{\mathrm{a}} \pm 0.90$ & 0.365 \\
\hline Magnesium(Mg)(mg/100g) & $5.0^{\mathrm{a}} \pm 0.01$ & $5.13^{\mathrm{a}} \pm 0.01$ & $5.09^{\mathrm{a}} \pm 0.02$ & 0.038 \\
\hline Iron (Fe)(mg/100g) & $0.91^{\mathrm{a}} \pm 0.05$ & $0.89^{\mathrm{a}} \pm 0.02$ & $0.90^{\mathrm{a}} \pm 0.03$ & 0.008 \\
\hline
\end{tabular}

Means in the same row with different letter are significantly different $(\mathrm{P} \leq 0.05)$.

Table (3): Effect of pH degrees on amino acids contents of collagen hydrolysate extraction.

\begin{tabular}{|l|c|c|c|}
\hline \multirow{2}{*}{ Amino acids gm/100g } & \multicolumn{3}{|c|}{ Different degree of pH } \\
\cline { 2 - 4 } & PH 4.00 & pH 6.50 & pH 9.00 \\
\hline Hydroxyproline & 76.35 & 54.78 & 48.91 \\
\hline Aspartic & 58.11 & 53.56 & 45.63 \\
\hline Therionine & 53.02 & 55.21 & 18.92 \\
\hline Serine & 26.31 & 22.31 & 98.05 \\
\hline Glutamic & 91.20 & 95.14 & 295.43 \\
\hline Glycine & 311.90 & 306.23 & 185.90 \\
\hline Alanine & 141.21 & 168.11 & 18.25 \\
\hline Valine & 19.30 & 18.73 & 11.95 \\
\hline Isoleucine & 10.33 & 11.12 & 35.91 \\
\hline Leucine & 20.84 & 26.24 & 1.86 \\
\hline Tyrosine & 1.16 & 1.47 & 18.93 \\
\hline Phenyl alanine & 12.16 & 15.21 & 13.10 \\
\hline Histidine & 9.71 & 10.36 & 25.83 \\
\hline Lysine & 28.30 & 26.71 & 5.11 \\
\hline Arginine & 5.36 & 5.25 & 104.30 \\
\hline Proline & 118.16 & 113.38 & 5.20 \\
\hline Hydroxylysine & 5.45 & 5.32 & 9.69 \\
\hline Methionine & 11.13 & 10.87 & \\
\hline
\end{tabular}

Table (4): Effect of different pH degrees on the chemical quality attributes of the extracted collagen hydrolysate from chicken feet.

\begin{tabular}{|l|c|c|c|c|}
\hline \multirow{2}{*}{ Item } & \multicolumn{3}{|c|}{ Different degree of pH } & \multirow{2}{*}{ LSD } \\
\cline { 2 - 5 } TVN (mg/100mg) & PH 4.00 & pH 6.50 & pH 9.00 & \\
\hline TBA (mg malonaldehyde/kg) & $8.75^{\mathrm{a}} \pm 0.35$ & $4.35^{\mathrm{c}} \pm 0.20$ & $6.80^{\mathrm{b}} \pm 0.50$ & 1.301 \\
\hline $\mathrm{pH}$ & $0.196^{\mathrm{a}} \pm 0.03$ & $0.217^{\mathrm{a}} \pm 0.06$ & $0.250^{\mathrm{a}} \pm 0.07$ & 0.318 \\
\hline
\end{tabular}

Means in the same row with different letter are significantly different $(\mathrm{P} \leq 0.05)$.

$\mathrm{TVN}=$ Total volatile nitrogen. $\mathrm{TBA}=$ Thiobarbituric acid. 


\subsection{Effect of different $\mathrm{pH}$ degrees on yield, rehydration ratio and water activity of collagen hydrolysate}

The effect of different $\mathrm{pH}$ degrees on yield, rehydration ratio and water activity of collagen hydrolysate was studied and the obtained results are shown in Table (5).

The obtained results in Table (5) indicated that no-significant differences were noticed for yield of collagen hydrolysate produced at different degrees of $\mathrm{pH}(4.0,6.5$ and 9.0). However, the highest value of yield was produced at $\mathrm{pH} 9.0$ followed by that produced at $\mathrm{pH} \quad 4.0$ then that produced at $\mathrm{pH}$ 6.5, respectively. These results agreed with these of Wei et al. (2013), who found that yield of extracted collagen hydrolysate from tilapia skin fish at $\mathrm{pH} 4.0, \mathrm{pH} 6.5$ and 9.0 was 13, 11 and $14 \%$, respectively.

Rehydration ratio is very important to a dried product and is an indicator of quality criterion in most dried foods. It is an indicator of cellular and structural disintegration that occurs during dehydration. The rehydration rate are important characteristics of many products, related to their later preparation for consumption (Jokić et al., 2009). The obtained results pointed that the collagen hydrolysate produced at $\mathrm{pH} 4.0$ had the highest value of rehydration ratio when compared with the collagen hydrolysate produced at $\mathrm{pH} 9.0$ and 6.5. This may be due to the collagen hydrolysate produced at $\mathrm{pH} 4.0$ had the highest content of protein and the lowest content of moisture compared with the collagen hydrolysate produced at $\mathrm{pH} 9.0$ and 6.5 (Table 2).

It is known that water affect the activity of the enzymes and microorganisms. The water activity required for growth of most bacteria, fungi and yeasts ranged from 0.61 to 0.97 (Anthony and Fontana, 2008). So, water activity is consided one of the most important tests for dried foods due to its relation to it's shelf life. The results presented in Table (5) showed that water activity values of the collagen hydrolysate produced at different degrees of $\mathrm{pH}(4.0,6.5$ and $9.0)$. These results indicated the water activity values of the collagen hydrolysate produced at $\mathrm{pH}$ degrees of 4.0, 6.5 and 9.0 were $0.421,0.438$ and 0.429 , respectevily, it is clear that different treatments of dried collagen hydrolysate is sufficient to minimize microbial growth.

\subsection{Chemical compositions of the raw materials}

The chemical compositions of raw materials under investigation are presented in Table (6). It could be noticed that the hard wheat flour $(72 \%$ ext.) and yellow corn flour contained the highest value of nitrogen free extract (84.07 and $83.99 \%$ respectively). However ash contents were 1.70 and $1.59 \%$, respectively, crude fiber contents were 0.7 and $1.0 \%$, respectively and fat contents were 0.87 and $3.11 \%$, respectively. Meanwhile, the chicken feet collagen hydrolysate contained the highest values of protein $(86.96 \%)$ but had the lowest value of nitrogen free extract (7.03\%), moreover, chicken feet collagen hydrolysate contained , $0.93 \%$ fat and $5.08 \%$ ash. These results confirmed those obtained by Hashim et al., (2014).

The minerals content of hard wheat flour ( $72 \%$ ext.), yellow corn flour and chicken feet collagen hydrolysate are shown in Table (6). Calcium contents were found to be $30.10,21.10$ and $88.00 \mathrm{mg} / 100 \mathrm{gm}$, magnesium contents were $159.22,98.71$ and $5.00 \mathrm{mg} / 100 \mathrm{gm}$ and iron contents were $2.05,4.65$ and $0.91 \mathrm{mg} / 100 \mathrm{gm}$ for hard wheat flour ( $72 \%$ ext.), yellow corn flour and chicken feet collagen hydrolysate, respectively.

\subsection{Sensory evaluation of the produced instant noodles}

From the presented results in Tables (7) it could be noticed that the sensory characteristics values were decreased with increasing the level of chicken feet collagen hydrolysate supplementation. Also, it could be noticed that instant noodles produced from hard wheat flour or yellow corn flour supplemented with chicken feet collagen hydrolysate until level $30 \%$, still have good overall acceptability. Moreover, data revealed that no significant differences were found between 10 and 20\% levels of chicken feet collagen hydrolysate, which were 90.00 and $89.00 \%$ for blends 1,2 , respectively, and 93.00 and $91.67 \%$ for blends 5, 6, respectively. So, supplementation levels of 10,20 and $30 \%$ were selected to study their chemical composition, amino acids and cooking quality parameters.

\subsection{Amino acids content of the raw materials and instant noodles}

Amino acids of raw materials are presented in Table (8A). The results showed that hard wheat flour contained the highest value of isoleucine, 
lysine, methionine, valine, tryptophan, cystine, arginine and aspartic compared with yellow corn flour and chicken feet collagen hydrolysate. These results agreed with those reported by Abd El-salam et al. (2017). However, yellow corn flour had the highest value of leucine, phenylalanine, glutamic, serine and tyrosine compared to other raw materials while, chicken feet collagen hydrolysate contained the highest value of threonine, alanine, glysine and proline compared with other raw materials. These results agree with those reported by $\lim$ et al. (2013). On the other hand chicken feet collagen hydrolysate had only hydroxylysine and hydroxyproline due to the thermal treatment through cooking of chicken feet (Morimura et al., 2002).

Table (5): Effect of different pH degree on yield, rehydration ratio and water activity of extracted collagen hydrolysate from chicken feet.

\begin{tabular}{|l|c|c|c|c|}
\hline \multirow{2}{*}{ Item } & \multicolumn{3}{|c|}{ Different degree of $\mathbf{~ p H}$} & \multirow{2}{*}{ LSD } \\
\cline { 2 - 4 } & $\mathrm{PH} 4.00$ & $\mathrm{pH} 6.50$ & $\mathrm{pH} 9.00$ & \\
\hline Yield (\%) & $13.85 \mathrm{a} \pm 1.13$ & $12.30 \mathrm{a} \pm 1.0$ & $14.20 \mathrm{a} \pm 1.20$ & 1.932 \\
\hline Rehydration ratio & $4.81 \mathrm{a} \pm 0.25$ & $4.58 \mathrm{c} \pm 0.10$ & $4.68 \mathrm{~b} \pm 0.15$ & 0.087 \\
\hline Water activity & $0.421 \mathrm{c} \pm 0.01$ & $0.438 \mathrm{a} \pm 0.01$ & $0.429 \mathrm{~b} \pm 0.01$ & 0.006 \\
\hline
\end{tabular}

Means in the same row with different letter are significantly different $(\mathrm{P} \leq 0.05)$.

Table (6): Chemical composition of raw materials (on dry weight basis).

\begin{tabular}{|l|c|c|c|}
\hline \multicolumn{1}{|c|}{ Component } & Hard wheat flour(72\% ext.) & Yellow corn flour & Chicken feet collagen hydrolysate \\
\hline Moisture(\%) & 9.11 & 12.64 & 7.13 \\
\hline Protein (\%) & 12.66 & 10.31 & 86.96 \\
\hline Ash (\%) & 1.70 & 1.59 & 5.08 \\
\hline Crude Fiber (\%) & 0.70 & 1.00 & --- \\
\hline Crude fat (\%) & 0.87 & 3.11 & 0.93 \\
\hline Nitrogin free extract (\%) & 84.07 & 83.99 & 7.03 \\
\hline Calcium(Ca) (mg/100g) & 30.10 & 21.10 & 88.00 \\
\hline Magnesium (Mg)(mg/100g) & 159.22 & 98.71 & 5.00 \\
\hline Iron (Fe)(mg/100g) & 2.05 & 4.65 & 0.91 \\
\hline
\end{tabular}

Table (7): Sensory evaluation of instant hard wheat flour and yellow corn flour noodles supplemented with chicken feet collagen hydrolysate.

\begin{tabular}{|l|c|c|c|c|c|c|c|}
\hline \multirow{2}{*}{ Sample } & $\begin{array}{c}\text { Appearance } \\
(\mathbf{2 0})\end{array}$ & $\begin{array}{c}\text { Colour } \\
(\mathbf{2 0})\end{array}$ & $\begin{array}{c}\text { Tenderness } \\
(\mathbf{2 0})\end{array}$ & $\begin{array}{c}\text { Flavour } \\
(\mathbf{2 0})\end{array}$ & $\begin{array}{c}\text { Stickiness } \\
(\mathbf{2 0})\end{array}$ & $\begin{array}{c}\text { Overall } \\
\text { acceptability(100) }\end{array}$ & Acceptance \\
\cline { 2 - 8 } & \multicolumn{7}{|c|}{ Hard wheat flour instant noodles } \\
\hline Control & $18.00^{\mathrm{a}}$ & $19.00^{\mathrm{a}}$ & $15.00^{\mathrm{b}}$ & $15.00^{\mathrm{b}}$ & $16.00^{\mathrm{b}}$ & $83.00^{\mathrm{c}}$ & $\mathrm{G}$ \\
\hline Blend (1) & $19.00^{\mathrm{a}}$ & $19.00^{\mathrm{a}}$ & $18.00^{\mathrm{a}}$ & $17.00^{\mathrm{ab}}$ & $17.00^{\mathrm{ab}}$ & $90.00^{\mathrm{a}}$ & $\mathrm{V}$ \\
\hline Blend (2) & $18.00^{\mathrm{a}}$ & $18.00^{\mathrm{a}}$ & $17.00^{\mathrm{ab}}$ & $18.00^{\mathrm{a}}$ & $18.00^{\mathrm{a}}$ & $89.00^{\mathrm{ab}}$ & $\mathrm{V}$ \\
\hline Blend (3) & $16.00^{\mathrm{b}}$ & $16.00^{\mathrm{b}}$ & $17.00^{\mathrm{ab}}$ & $18.00^{\mathrm{a}}$ & $18.00^{\mathrm{a}}$ & $85.00^{\mathrm{bc}}$ & $\mathrm{G}$ \\
\hline Blend (4) & $13.00^{\mathrm{c}}$ & $13.00^{\mathrm{c}}$ & $14.00^{\mathrm{b}}$ & $13.00^{\mathrm{c}}$ & $16.00^{\mathrm{b}}$ & $69.67^{\mathrm{d}}$ & Un s \\
\hline LSD 0.5 & 1.82 & 1.82 & 2.30 & 2.20 & 1.63 & 4.41 & ------ \\
\hline \multicolumn{7}{|c|}{ Yellow corn flour instant noodles } & $\mathrm{G}$ \\
\hline Control 2 & $17.00^{\mathrm{ab}}$ & $17.33^{\mathrm{a}}$ & $16.67^{\mathrm{b}}$ & $17.33^{\mathrm{bc}}$ & $18.00^{\mathrm{b}}$ & $83.00^{\mathrm{b}}$ & $\mathrm{V}$ \\
\hline Blend (5) & $18.67^{\mathrm{a}}$ & $17.67^{\mathrm{a}}$ & $18.67^{\mathrm{a}}$ & $18.67^{\mathrm{a}}$ & $19.33^{\mathrm{ab}}$ & $93.00^{\mathrm{a}}$ & $\mathrm{V}$ \\
\hline Blend (6) & $17.00^{\mathrm{ab}}$ & $16.67^{\mathrm{a}}$ & $18.67^{\mathrm{a}}$ & $18.33^{\mathrm{ab}}$ & $19.67^{\mathrm{a}}$ & $91.67^{\mathrm{a}}$ & $\mathrm{G}$ \\
\hline Blend (7) & $16.00^{\mathrm{b}}$ & $14.67^{\mathrm{b}}$ & $16.33^{\mathrm{b}}$ & $16.67^{\mathrm{c}}$ & $19.33^{\mathrm{ab}}$ & $84.00^{\mathrm{b}}$ & $\mathrm{G}$ \\
\hline Blend (8) & $13.00^{\mathrm{c}}$ & $12.33^{\mathrm{c}}$ & $12.33^{\mathrm{c}}$ & $12.67^{\mathrm{d}}$ & $14.00^{\mathrm{c}}$ & $64.33^{\mathrm{c}}$ & $\mathrm{Un} \mathrm{s}$ \\
\hline LSD 0.5 & 1.96 & 1.33 & 1.56 & 1.33 & 1.57 & 4.84 & ----- \\
\hline
\end{tabular}

Means in the same column with different letter or letters for wheat or yellow corn noodles are significantly different $(\mathrm{P} \leq 0.05)$ 90-100 Very Good (V). 80-89 Good (G). 70-79 Satisfactory (S). Less Than 70 Unsatisfactory (Un s).

Control $(1)=100 \%$ HWF Control (2) $=100 \%$ YCF.

Blend (2) $=80 \% \mathrm{HWF}+20 \% \mathrm{CFCH}$

Blend (4) $=60 \% \mathrm{HWF}+40 \% \mathrm{CFCH}$

Blend $(6)=80 \% \mathrm{YCF}+20 \% \mathrm{CFCH}$

Blend $(8)=60 \% \mathrm{YCF}+40 \% \mathrm{CFCH}$.

Blend(1) $=90 \% \mathrm{HWF}+10 \% \mathrm{CFCH}$

Blend $(3)=70 \% \mathrm{HWF}+30 \% \mathrm{CFCH}$

Blend $(5)=90 \% \mathrm{YCF}+10 \% \mathrm{CFCH}$

Blend $(7)=70 \% \mathrm{YCF}+30 \% \mathrm{CFCH}$ 
Table (8A): Amino acids content of hard wheat flour (72\%ext.), yellow corn flour and chicken feet collagen hydrolysate (gm / 100 gm protein).

\begin{tabular}{|l|c|c|c|}
\hline \multicolumn{1}{|c|}{ Amino acids } & Hard wheat flour (72\% ext.) & Yellow corn flour & chicken feet collagen hydrolysate \\
\hline Isoleucine & 6.48 & 4.45 & 1.03 \\
\hline Leucine & 8.52 & 11.78 & 2.08 \\
\hline Lysine & 7.10 & 2.82 & 2.83 \\
\hline Methionine & 2.20 & 1.87 & 1.11 \\
\hline Phenylalanine & 4.20 & 4.52 & 1.22 \\
\hline Threonine & 4.72 & 3.90 & 5.31 \\
\hline Valine & 6.09 & 5.00 & 1.93 \\
\hline Tryptophan & 1.20 & 0.68 & $\mathrm{ND}$ \\
\hline Cystine & 1.90 & 1.28 & $\mathrm{ND}$ \\
\hline Alanine & 7.19 & 6.96 & 14.12 \\
\hline Arginine & 7.30 & 5.25 & 0.54 \\
\hline Aspartic & 11.03 & 6.41 & 5.81 \\
\hline Glutamic & 13.00 & 18.50 & 9.12 \\
\hline Glycine & 5.11 & 3.32 & 31.19 \\
\hline Histidine & 2.58 & 2.97 & 0.97 \\
\hline Proline & 3.95 & 9.60 & 11.82 \\
\hline Serine & 4.14 & 4.65 & 2.63 \\
\hline Tyrosin & 3.29 & 6.04 & 0.13 \\
\hline Hydroxylysine & $\mathrm{ND}$ & $\mathrm{ND}$ & 0.55 \\
\hline Hydroxyproline & $\mathrm{ND}$ & $\mathrm{ND}$ & 7.61 \\
\hline
\end{tabular}

Results in Table (8B) showed amino acid contents for blends of instant noodles produced from hard wheat and yellow corn flour supplemented with chicken feet collagen hydrolysate. From these results, it could be noticed that hard wheat flour instant noodles or yellow corn flour instant noodles with $30 \%$ of chicken feet collagen hydrolysate showed the highest value of threonine, alanine, glysine, proline, hydroxylysine and hydroxyproline compared to other blends.

\subsection{Chemical composition of the produced instant noodles}

The data in Table (9) showed the chemical composition of the produced instant noodles from hard wheat or yellow corn flour supplemented with chicken feet collagen hydrolysate. All blends showed high values of protein and ash and low value of crude fiber and nitrogen free extract compared with the control sample (instant noodles without chicken feet collagen hydrolysate). All blends of hard wheat flour instant noodles contained protein varied from 20.13 to $34.95 \%$, ash from 1.94 to $2.72 \%$, crude fiber from 0.64 to $0.51 \%$, crude fat from 0.87 to $0.89 \%$ and available nitrogen free extract from 76.42 to $60.93 \%$ while the control sample contained $12.66 \%$ protein, $1.70 \%$ ash, $0.70 \%$ crude fiber, $0.87 \%$ crude fat and $84.07 \%$ nitrogen free extract Also yellow corn flour instant noodles with chicken feet collagen hydrolysate contained protein varied from 25.54 to $33.30 \%$, ash varied from 2.27 to $2.63 \%$, crude fiber varied from 0.80 to $0.70 \%$ and fat varied from 2.76 to $2.46 \%$ and nitrogen free extract varied from 68.72 to $60.91 \%$ while the control sample contained $12.66 \%$ protein, 1.70 $\%$ ash, $0.70 \%$ crude fiber, $0.87 \%$ fat and 84.07 $\%$.nitrogen free extract. These results are in agreement with those found by Gomez-Guillen et al., (2011).

The data presented in the same Table showed also the mineral contents of instant noodles of all blends which contained chicken feet collagen hydrolysate. Such blends showed high values for calcium content, compared to the control sample. Hence, instant noodles blends containing chicken feet collagen hydrolysate are favorable because of their high content of important mineral which depend upon the substitution levels by the chicken feet collagen hydrolysate.

\subsection{Cooking quality of the produced instant noodles}

The cooking quality of instant noodles produced from hard wheat flour or corn flour supplemented with 10, 20 and $30 \%$ of natural collagen hydrolysate extracted from chicken feet were evaluated and the obtained data are presented in Table (10). The cooked weight gain $\%$ and cooked volume gain $\%$ of instant noodles of all blends were higher than the control sample and the highest gain for weight and volume was noticed with supplementation 
Table (8B): Amino acids content of hard wheat flour and yellow corn flour instant noodles supplemented with chicken feet collagen hydrolysate. (gm/ $100 \mathrm{gm}$ protein).

\begin{tabular}{|c|c|c|c|c|c|c|}
\hline \multirow[t]{2}{*}{ Amino acids } & \multicolumn{3}{|c|}{$\begin{array}{l}\text { hard wheat flour Instant noodles } \\
\text { supplemented with chicken feet } \\
\text { collagen hydrolysate. }\end{array}$} & \multicolumn{3}{|c|}{$\begin{array}{l}\text { yellow corn flour Instant noodles } \\
\text { supplemented with chicken feet collagen } \\
\text { hydrolysate }\end{array}$} \\
\hline & Blend(1) & Blend(2) & Blend(3) & Blend(4) & Blend (5) & Blend (6) \\
\hline Isoleucine & 5.94 & 5.39 & 4.85 & 4.11 & 3.77 & 3.42 \\
\hline Leucine & 7.88 & 7.23 & 6.59 & 10.81 & 9.84 & 8.87 \\
\hline Lysine & 6.67 & 6.25 & 5.82 & 2.82 & 2.82 & 2.82 \\
\hline Methionine & 2.09 & 1.98 & 1.87 & 1.79 & 1.72 & 1.64 \\
\hline Phenylalanine & 3.90 & 3.60 & 3.27 & 4.19 & 3.86 & 3.53 \\
\hline Threonine & 4.78 & 4.84 & 4.90 & 4.04 & 4.18 & 4.32 \\
\hline Valine & 5.67 & 5.26 & 4.84 & 4.69 & 4.39 & 4.08 \\
\hline Tryptophan & 1.08 & 0.96 & 0.84 & 061 & 0.54 & 0.48 \\
\hline Cystine & 1.71 & 1.52 & 1.33 & 1.15 & 1.02 & 0.90 \\
\hline Alanine & 7.88 & 8.58 & 9.27 & 7.68 & 8.39 & 9.11 \\
\hline Arginine & 6.62 & 5.95 & 5.27 & 4.78 & 4.31 & 3.84 \\
\hline Aspartic & 10.51 & 9.98 & 9.46 & 6.35 & 6.29 & 6.23 \\
\hline Glutamic & 12.61 & 12.22 & 11.84 & 17.56 & 16.63 & 15.69 \\
\hline Glycine & 7.72 & 10.33 & 12.93 & 6.11 & 8.89 & 11.68 \\
\hline Histidine & 2.42 & 2.26 & 2.10 & 2.77 & 2.57 & 2.37 \\
\hline Proline & 4.74 & 5.52 & 6.31 & 9.82 & 10.04 & 10.27 \\
\hline Serine & 3.99 & 3.84 & 3.69 & 4.47 & 4.25 & 4.04 \\
\hline Tyrosin & 2.97 & 2.66 & 2.34 & 5.45 & 4.86 & 4.27 \\
\hline Hydroxylysine & 0.06 & 0.11 & 0.17 & 0.06 & 0.11 & 0.17 \\
\hline Hydroxyproline & 0.76 & 1.52 & 2.28 & 0.76 & 1.52 & 2.28 \\
\hline
\end{tabular}

Blend $(\mathbf{1})=90 \% \mathrm{HWF}+10 \% \mathrm{CFCH}$

Blend(2) $=80 \% \mathrm{HWF}+20 \% \mathrm{CFCH}$

Blend(3) $=70 \% \mathrm{HWF}+30 \% \mathrm{CFCH} \quad$ Blend(4) $=90 \% \mathrm{YCF}+10 \% \mathrm{CFCH}$

Blend $(\mathbf{5})=80 \% \mathrm{YCF}+20 \% \mathrm{CFCH} \quad$ Blend $(\mathbf{6})=70 \% \mathrm{YCF}+30 \% \mathrm{CFCH}$

Table (9): Chemical composition of hard wheat flour and yellow corn flour instant noodles supplemented with chicken feet collagen hydrolysate. (on dry weight basis).

\begin{tabular}{|c|c|c|c|c|c|c|c|c|c|}
\hline \multirow[t]{2}{*}{ Sample } & $\begin{array}{l}\text { Protein } \\
\%\end{array}$ & $\begin{array}{c}\text { Ash } \\
\%\end{array}$ & $\begin{array}{r}\text { Crude } \\
\text { fiber\% }\end{array}$ & $\begin{array}{l}\text { Crude } \\
\text { fat \% }\end{array}$ & $\begin{array}{l}\text { Nitrogen free } \\
\text { extract } \%\end{array}$ & $\begin{array}{c}\text { Calories } \\
\%\end{array}$ & $\begin{array}{l}\text { Calcium( } \\
\text { mg/100g) }\end{array}$ & $\begin{array}{c}\text { Magnesium } \\
\text { (mg/100g) }\end{array}$ & $\begin{array}{c}\operatorname{Iron}(\mathrm{mg} / \mathbf{1} \\
\mathbf{0 0 g})\end{array}$ \\
\hline & \multicolumn{9}{|c|}{ Hard wheat flour instant noodles } \\
\hline Control 1 & $12.66^{\mathrm{d}}$ & $1.70^{\mathrm{d}}$ & $0.70^{\mathrm{a}}$ & $0.87^{\mathrm{a}}$ & $84.07^{\mathrm{a}}$ & $394.75^{\mathrm{a}}$ & $30.10^{\mathrm{d}}$ & $159.22^{\mathrm{a}}$ & $2.05^{\mathrm{a}}$ \\
\hline Blend 1 & $20.13^{\mathrm{c}}$ & $1.94^{\mathrm{c}}$ & $0.64^{\mathrm{ab}}$ & $0.87^{\mathrm{a}}$ & $76.42^{b}$ & $394.03^{\mathrm{b}}$ & $35.89^{\mathrm{c}}$ & $143.80^{\mathrm{b}}$ & $1.94^{\mathrm{b}}$ \\
\hline Blend 2 & $27.52^{\mathrm{b}}$ & $2.39^{\mathrm{b}}$ & $0.56^{\mathrm{bc}}$ & $0.88^{\mathrm{a}}$ & $68.65^{\mathrm{c}}$ & $392.60^{\mathrm{c}}$ & $41.68^{\mathrm{b}}$ & $128.38^{\mathrm{c}}$ & $1.82^{\mathrm{c}}$ \\
\hline Blend 3 & $34.95^{\mathrm{a}}$ & $2.72^{\mathrm{a}}$ & $0.51^{\mathrm{c}}$ & $0.89^{\mathrm{a}}$ & $60.93^{\mathrm{d}}$ & $391.53^{\mathrm{d}}$ & $47.47^{\mathrm{a}}$ & $112.95^{\mathrm{d}}$ & $1.71^{\mathrm{c}}$ \\
\hline \multirow[t]{2}{*}{ LSD } & 0.19 & 0.15 & 0.10 & 0.11 & 0.52 & 0.58 & 0.47 & 1.24 & 0.07 \\
\hline & \multicolumn{9}{|c|}{ Yellow corn flour instant noodles } \\
\hline Control 2 & $10.32^{\mathrm{d}}$ & $1.59^{\mathrm{d}}$ & $1.03^{\mathrm{a}}$ & $3.11^{\mathrm{a}}$ & $83.95^{\mathrm{a}}$ & $405.07^{\mathrm{a}}$ & $21.10^{\mathrm{d}}$ & $98.71^{\mathrm{a}}$ & $4.65^{\mathrm{a}}$ \\
\hline Blend 4 & $17.93^{\mathrm{c}}$ & $1.94^{\mathrm{c}}$ & $0.91^{\mathrm{ab}}$ & $2.89^{\mathrm{b}}$ & $76.33^{b}$ & $403.05^{\mathrm{b}}$ & $27.79^{\mathrm{c}}$ & $89.34^{\mathrm{b}}$ & $4.28^{\mathrm{a}}$ \\
\hline Blend 5 & $25.54^{\mathrm{b}}$ & $2.27^{\mathrm{b}}$ & $0.80^{\mathrm{bc}}$ & $2.67^{c}$ & $68.72^{\mathrm{c}}$ & $401.07^{\mathrm{C}}$ & $34.48^{b}$ & $79.97^{c}$ & $3.90^{\mathrm{b}}$ \\
\hline Blend 6 & $33.30^{\mathrm{a}}$ & $2.63^{\mathrm{a}}$ & $0.70^{\mathrm{c}}$ & $2.46^{\mathrm{d}}$ & $60.91^{\mathrm{d}}$ & $398.98^{d}$ & $41.17^{\mathrm{a}}$ & $70.60^{d}$ & $3.53^{b}$ \\
\hline LSD & 0.13 & 0.06 & 0.15 & 0.05 & 0.23 & 0.84 & 0.50 & 0.45 & 0.50 \\
\hline
\end{tabular}

Means in the same column with different letter or letters for wheat or yellow corn noodles are significantly different $(\mathrm{P} \leq 0.05)$.

Control $1=100 \%$ HWF

Blend 1= 90\% $\mathrm{HWF}+10 \% \mathrm{CFCH}$.

Blend $3=70 \% \mathrm{HWF}+30 \% \mathrm{CFCH}$

Blend 5 $=80 \% \mathrm{YCF}+20 \% \mathrm{CFCH}$
Control 2 $=100 \% \mathrm{YCF}$

Blend $2=80 \% \mathrm{HWF}+20 \% \mathrm{CFCH}$

Blend $4=90 \% \mathrm{YCF}+10 \% \mathrm{CFCH}$

Blend $6=70 \% \mathrm{YCF}+30 \% \mathrm{CFCH}$ 
Table (10): Cooking quality properties of hard wheat flour and yellow corn flour instant noodles supplemented with chicken feet collagen hydrolysate.

\begin{tabular}{|l|c|c|c|c|}
\hline \multicolumn{1}{|c|}{ Sample } & Cooking time (min) & weight gain(\%) & volume gain(\%) & Cooking lose (T.S.S\%) \\
\hline \multicolumn{7}{|c|}{ Hard wheat flour instant noodles } \\
\hline Control (1) & $7.50^{\mathrm{a}}$ & $230^{\mathrm{c}}$ & $205^{\mathrm{d}}$ & $6.00^{\mathrm{a}}$ \\
\hline Blend (1) & $7.00^{\mathrm{ab}}$ & $250^{\mathrm{b}}$ & $215^{\mathrm{c}}$ & $5.90^{\mathrm{a}}$ \\
\hline Blend (2) & $6.50^{\mathrm{bc}}$ & $270^{\mathrm{a}}$ & $235^{\mathrm{b}}$ & $5.00^{\mathrm{b}}$ \\
\hline Blend (3) & $6.00^{\mathrm{c}}$ & $285^{\mathrm{a}}$ & $250^{\mathrm{a}}$ & 0.70 \\
\hline LSD 0.5 & 0.55 & 0.25 & 28.1 & $7.00^{\mathrm{a}}$ \\
\hline \multicolumn{7}{|}{} \\
\hline Contro (2) & $4.80^{\mathrm{a}}$ & $180^{\mathrm{c}}$ & $195^{\mathrm{c}}$ & $6.50^{\mathrm{a}}$ \\
\hline Blend (4) & $4.50^{\mathrm{ab}}$ & $190^{\mathrm{bc}}$ & $210^{\mathrm{bc}}$ & $5.80^{\mathrm{b}}$ \\
\hline Blend (5) & $4.20^{\mathrm{b}}$ & $220^{\mathrm{ab}}$ & $230^{\mathrm{a}}$ & $5.20^{\mathrm{b}}$ \\
\hline Blend (6) & $4.00^{\mathrm{b}}$ & $250^{\mathrm{a}}$ & $240^{\mathrm{a}}$ & 0.87 \\
\hline LSD 0.5 & 0.94 & 9.40 & 19.97 & \\
\hline
\end{tabular}

Means in the same column with different letter or letters for wheat or yellow corn noodles are significantly different $(\mathrm{P} \leq 0.05)$.

Control $1=100 \% \mathrm{HWF}$

Blend 1= 90\% HWF + 10\% CFCH

Blend $3=70 \% \mathrm{HWF}+30 \% \mathrm{CFCH}$

Blend $5=80 \% \mathrm{YCF}+20 \% \mathrm{CFCH}$
Control 2=100\% YCF.

Blend $2=80 \% \mathrm{HWF}+20 \% \mathrm{CFCH}$

Blend $4=90 \% \mathrm{YCF}+10 \% \mathrm{CFCH}$

Blend $6=70 \% \mathrm{YCF}+30 \% \mathrm{CFCH}$ level of $30 \%$ of natural collagen for both hard wheat and yellow corn flour instant noodles. Meanwhile, cooking loss \% was decreased with increasing the natural collagen percentage for both hard wheat and yellow corn flour instant noodles. So, the addition of collagen hydrolysate improved the cooking quality of instant noodles.

\subsection{Firmness of instant noodles}

The data presented in Table (11) showed the firmness values of instant noodles produced from hard wheat or yellow corn flour supplemented with 10, 20 and $30 \%$ of natural collagen extracted from chicken feet, compared to the control sample. The firmness values were increased with increasing of natural collagen percentage for both hard wheat and yellow corn flour instant noodles. The increase of instant noodles firmness values may be related to the addition of components rich in protein that, probably have a significant influence in the reinforcement of the gluten network as reported by Abd El-Salam (2005).

\subsection{Recommended dietary allowances} (RDA\%) of the produced instant noodles

The percentages of the recommended dietary allowances (RDA\%) which provided from $100 \mathrm{~g}$ of instant noodles for age of $31-50$ years old are shown in Table (12). It could be observed that all values of RDA \% for protein was high in instant noodles produced from hard wheat flour, since it ranged from 35.95 to $62.41 \%$ for males and ranged from 43.76 to $75.98 \%$ for females compared to control sample which showed RDA $\%$ of 22.61 and $27.52 \%$ for males and females, respectively, moreover, calcium showed RDA\% ranged from 3.59 to $4.75 \%$ for both males and females, respectively, compared to the control

Table (11): Effect of the steaming process on firmness of hard wheat and yellow corn flour instant noodles supplemented with chicken feet collagen hydrolysate.

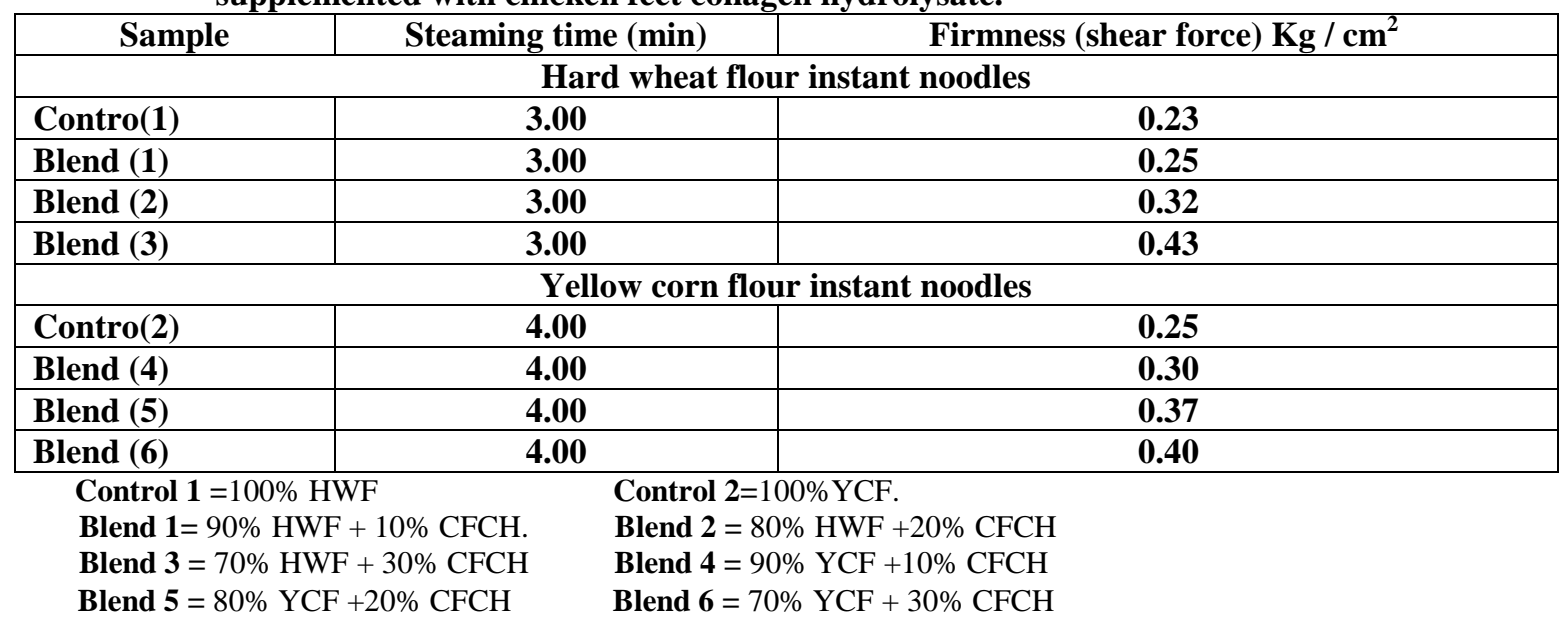


Table (12): Percentages of the recommended dietary allowances (RDA\%) which provided from 100 gm hard wheat flour and yellow corn flour instant noodles supplemented with chicken feet collagen hydrolysate for some nutrients for adults (31-50 years).

\begin{tabular}{|c|c|c|c|c|c|c|c|c|}
\hline \multirow[t]{3}{*}{ Sample } & $\begin{array}{c}\mathrm{RDA}^{* *} \\
\text { Protein } \\
(56 \mathrm{~g})\end{array}$ & $\begin{array}{c}\text { RDA** } \\
\text { Energy } \\
\text { (2700kcal) }\end{array}$ & $\begin{array}{c}\mathrm{RDA}^{* *} \\
\text { Ca } \\
(\mathbf{1 0 0 0 m g )})\end{array}$ & $\begin{array}{c}\mathrm{RDA}^{* *} \\
\mathbf{F e} \\
(\mathbf{8 m g})\end{array}$ & $\begin{array}{c}\text { RDA** } \\
\text { Protein } \\
(\mathbf{4 6 g})\end{array}$ & $\begin{array}{c}\mathrm{RDA}^{* *} \\
\text { Energy } \\
\text { (2000kcal) }\end{array}$ & $\begin{array}{c}\mathrm{RDA}^{* *} \\
\mathbf{C a} \\
(\mathbf{1 0 0 0 \mathrm { mg }})\end{array}$ & $\begin{array}{c}\text { RDA** }^{* *} \\
\text { Fe } \\
(\mathbf{1 8 m g}) \\
\end{array}$ \\
\hline & \multicolumn{8}{|c|}{ Hard wheat flour instant noodles } \\
\hline & \multicolumn{4}{|c|}{ RDA \%* Males } & \multicolumn{4}{|c|}{ RDA \%* Females } \\
\hline Control (1) & 22.61 & 14.62 & 3.01 & 25.63 & 27.52 & 19.74 & 3.01 & 11.39 \\
\hline Blend (1) & 35.95 & 14.59 & 3.59 & 24.25 & 43.76 & 19.70 & 3.59 & 10.78 \\
\hline Blend (2) & 49.14 & 14.54 & 4.17 & 22.75 & 59.83 & 19.63 & 4.17 & 10.11 \\
\hline \multirow[t]{3}{*}{ Blend (3) } & 62.41 & 14.50 & 4.75 & 21.38 & 75.98 & 19.58 & 4.75 & 9.50 \\
\hline & \multicolumn{8}{|c|}{$\begin{array}{l}\text { Yellow corn flour instant noodles } \\
\end{array}$} \\
\hline & \multicolumn{4}{|c|}{ RDA \%* Males } & \multicolumn{4}{|c|}{ RDA \%* Females } \\
\hline Sample & $\begin{array}{c}\mathrm{RDA}^{* *} \\
\text { Protein } \\
(\mathbf{5 6 g})\end{array}$ & $\begin{array}{c}\mathrm{RDA}^{* *} \\
\text { Energy } \\
\text { (27000kcal) }\end{array}$ & $\begin{array}{c}\mathrm{RDA}^{* *} \\
\text { Ca } \\
(\mathbf{1 0 0 0 \mathrm { mg }})\end{array}$ & $\begin{array}{c}\mathrm{RDA}^{* *} \\
\mathbf{F e} \\
(\mathbf{8 m g})\end{array}$ & $\begin{array}{c}\text { RDA** }^{* *} \\
\text { Protein } \\
\text { (46g) }\end{array}$ & $\begin{array}{c}\mathrm{RDA}^{* *} \\
\text { Energy } \\
\text { (2000kcal) }\end{array}$ & $\begin{array}{c}\mathrm{RDA}^{* *} \\
\text { Ca } \\
(\mathbf{1 0 0 0 \mathrm { mg }})\end{array}$ & $\begin{array}{l}\text { RDA** }^{* *} \\
\text { Fe } \\
(\mathbf{1 8 m g})\end{array}$ \\
\hline Control (2) & 18.43 & 15.00 & 2.11 & 58.13 & 22.43 & 20.25 & 2.11 & 25.83 \\
\hline Blend (4) & 32.02 & 14.93 & 2.78 & 53.50 & 38.98 & 20.15 & 2.78 & 23.78 \\
\hline Blend (5) & 45.61 & 14.85 & 3.45 & 48.75 & 55.52 & 20.05 & 3.45 & 21.67 \\
\hline Blend (6) & 59.46 & 14.78 & 4.12 & 44.13 & 72.39 & 19.95 & 4.12 & 19.61 \\
\hline
\end{tabular}

RDA\%*= value of nutrient in sample $\mathrm{x} 100$ / RDA for the same nutrient in reference.

RDA $* *=$ value of nutrient in reference.

Control(1) $=100 \%$ HWF

Blend $(\mathbf{1})=90 \% \mathrm{HWF}+10 \% \mathrm{CFCH}$.

Blend $(3)=70 \% \mathrm{HWF}+30 \% \mathrm{CFCH}$

Blend $(\mathbf{5})=90 \% \mathrm{YCF}+10 \% \mathrm{CFCH}$

Blend $(7)=70 \% \mathrm{YCF}+30 \% \mathrm{CFCH}$.

\section{Control (2) $=100 \% \mathrm{YCF}$}

Blend(2) $=80 \% \mathrm{HWF}+20 \% \mathrm{CFCH}$

Blend (4) $=60 \% \mathrm{HWF}+40 \% \mathrm{CFCH}$

Blend $(6)=80 \% \mathrm{YCF}+20 \% \mathrm{CFCH}$

Blend $(8)=60 \% \mathrm{YCF}+40 \% \mathrm{CFCH}$. sample which showed RDA \% of $3.01 \%$ for both males and females. Moreover, the same results showed also that all values of RDA \% for protein was high in instant noodles produced from yellow corn flour and ranged from 32.02 to $59.46 \%$ for males and ranged from 38.98 to $72.39 \%$ for females compared to the control sample which showed RDA \% of 18.43 and $22.43 \%$ for males and females, respectively, concerning calcium it showed RDA\% ranged from 2.78 to $4.12 \%$ for both males and females, respectively, compared to control sample which showed RDA \% of $2.11 \%$ for both males and females. The obtained results also indicated that energy values of all blends were found to be approximately the same. However, the control 1 and 2 showed higher values of iron content than all the studied blends.

\section{REFERENCES}

Abd El-Salam Amira M. (2005). Production of instant noodles from different flours of various extractions. M.Sc. Thesis, Food Tech. Dept., Fac. Agric., Banha Univ., Egypt.

Abd El-Salam Amira M., Morsy O.M. and Abd El Mawla E.M. (2017). Production and evaluation crackers and instant noodles supplement with spirulina algae. Curr, Sci., Int'l 06 (4): 908-919.

Aitken A., Casey J. C., Penny I. F. and Voyle C. A. (1962). Effect of drying temperature in the accelerated freeze of prok. J. Sci. Food Agric.,13,439- 448.

Amin R., Muphy N. and Edge J. (2002). Study of effect of a gluten free diet on glycemic control and weight gain in subjects with type 1 diabetes and celiac disease. Diabetes Care, 25, 1117-1122.

Anthony J. and Fontana Jr. (2008). Minimum Water Activity Limits for Growth of Microorganisms. Online ISBN: 9780470376454.

A.O.A.C. (2005). Official Methods of Analysis. Association of Official Analytical, Chemists 18th ed., Washington, DC, USA.

Cadden A.M. (1988) Moisture Sorption Characteristics of Several Food Fibers. J. Food Sci., 53: 1150-1155.

Choy A.L., Hughes J.F. and Small D.M. (2010). The effects of microbial transglutaminase, sodium. stearoyllactylate and water on the quality of instant fried noodles. Food Chem., 122: 957-964. 
Delgado L. M., Shologu N., Fuller K., and Zeugolis D. I. (2017). Acetic acid and pepsin result in high yield, high purity and low macrophage response collagen for biomedical applications. Biomed. Materials, 12(6):065009.

Dexter J., Mastuo J. and Kruger J. (1990). The spaghetti making quality of commercial durum wheat samples with variable amylose activity. Cereal Chem., 76: 405412.

Egan H., Kirk R.S. and Sawyer R. ( 1981). Pearson`s Chemical Analysis of Foods. $8^{\text {th }}$ ed. Churchill Livingstone. Longman Group Limited, U.K.

FAO/WHO (1973). Energy and protein requirement. FAO nutrition meeting report series No.52 FAO, Rome, Italy.

Gomez-Guillen M. C., Gim'enez B., opezCaballero M. E. L'. and MonteroM. P. (2011). Functional and bioactive properties of collagen and gelatin from alternative sources: a review. Food Hydrocolloids 25:1813-1827.

Hashim P., Mohd Ridzwan M. S. and Bakar J. (2014). Isolation and Characterization of Collagen from Chicken Feet, World Acad. Sci., Eng. and Tech., 8 (3): 250-254.

Hatanaka T., Kawakami K. and Uraji M. (2014). Inhibitory effect of collagen-derived tripeptides on dipeptidylpeptidase-IV activity. J. Enzyme Inhib. Med. Chem., 29(6): 823-828.

Hongdong S. and Bo L. (2017). Beneficial Effects of Collagen Hydrolysate: A Review on Recent Developments. Biomed. J. Sci. \& Tech. Res., 2(1) : 1-4.

Hou G. (2001). Oriental instant noodles. Advances in Food and Nutrition Research, 43, 143-193.

Jayathilakan K., Sultana K., Radhakrishna K. and Bawa A. S. (2010). Utilization of byproducts and waste materials from meat, poultry and fish processing industries: A review. J. Food Sci. Tech., 49(3): 278293.

Jokić S., Mujić I., Martinov M., Velić D., Bilić M.and Lukinac J. (2009). Influence of Drying Procedure on Colour and Rehydration Characteristic of Wild Asparagus. Czech J. Food Sci., 27, 171177.

Karim A. A. and Bhat R. (2009). Fish gelatin: properties, challenges, and prospects as an alternative to mammalian gelatins. Food Hydrocolloids, 23(3): 563-576.

Krokida M.K. and Marinos-Kouris D. (2003) Rehydration Kinetics of Dehydrated Products. J. Food Eng., 57, 1-7.

Lim D. G., Kim K. T., Lee K. H., Seo K. S. and Nam K. C. (2013). Physicochemical traits fatty acid and free amino acid composition of two-way crossbred pork belly. Korean J. Food Sci. of animal, 33: 189-197.

Mohamed H.A., Elsoukkary M.M., Doweidar M.M. and Atia A.A. (2004). Preparation, characterizations and health effects of functional biscuits containing iso flavones. Minufiya J. Agric. Res., 2(29): 425-434.

Morimura S., Nagata H. Uemura Y. Fahmi A., Shigematsu T. and Kida K. (2002). Development of an effective process for utilization of collagen from livestock and fish waste. Proc. Biochem., 37, 14031412.

Ohara H., Ichikawa S., Matsumoto H., Akiyama M. and Fujimoto N. (2010). Collagen-derived dipeptide, prolinehydroxyproline, stimulates cell proliferation and hyaluronic acid synthesis in cultured human dermal fibroblasts. J. Dermatol., 37(4): 330-338.

Oesser S., Adam M., Babel W. and Seifert J. (1999). Oral administration of 14C labeled gelatin hydrolysate leads to an accumulation of radioactivity in cartilage of mice (C57/BL). J. Nutr., 129(10): 1891-1895.

Park C.S., Hong B.H. and Baik B.K. (2004). Relationship between protein characteristics and instant noodle making quality of wheat flour. Cereal Chem. 81, (2): 159-164.

Polian F. A. (2012). Collagen extraction from chicken feet for jelly production. Acta Scientiarum. Technology Maringa, 34, (3): 345-351.

Rodrigues J. A. G., Quinderé A. L. G., Queiroz I. N. L., Coura C. O., Arajo G. S. and Benevides N. M. B.(2011). Purification, physical and chemical characterization, and anticoagulant activity of glycosaminoglycans isolated from the skin of Nile tilapia (Oreochromis niloticus). Acta Scientiarum. Technology, 33(3): 233-241. 
Sanchez- Alonso I., Jimenez A., Sura F.and Borderias A. J. (2008). Antioxidant protection of white grape pomace on restructured fish products during frozen storage. LWT-Food Sci. Technol., 41(1):42-50.

Shin S.N. and Kim S.K. (2003). Properties of instant noodle flours produced in Korea. Cereal Foods, World, 48: 310-314.

Slump P., Flissebaalje T. D. and Haaksman I. K. (1991).Tryptophan in food proteins -a comparison of 2 hydrolytic procedures. J. Sci. of Food and Agric., 55: 493-496.

Snedecor G. W. and Cochran W. G. (1980). Statistical methods $7^{\text {th }}$ ed. Iowa State Univ., Press. Ames., Iowa, USA.

Song H., Meng M., Cheng X., Li B. and Wang C. (2017). The effect of collagen hydrolysates from silver carp (Hypophthalmichthys molitrix) skin on UV-induced photo aging in mice: molecular weight affects skin repair. Food Funct. 8(4): 1538-1546.

Taha A. E., Dina M. S., Mahmoud F. S. A. K. and Ragab A. A. (2015). Utilization of chicken feet and skeleton meat for the production of dried chicken soup. Middle East J. Agric., 4(4): 938-948.

Walash D. E. and Cilles K. A. (1971). The influence of protein composition on spaghetti quality. Cereal Chem., 84: 544553.

Wei W., Zhonglei L., Junzhong L., Yuejun W., Shanhong L. and Mi S. (2013). Comparison between Thermal Hydrolysis and Enzymatic Proteolysis Processes for the Preparation of Tilapia Skin Collagen Hydrolysates. Czech J. Food Sci., 31( 1): $1-4$.

Winton A.L. and Winton R.B. (1958). Oxide distillation volumetric method for the determination of total volatile nitrogen. In "The Analysis of Foods" p.848 (Pub) John, Wiley and Sons, New york, U.S.A.

Yang J.I., Liang W.S., Chow C.J. and Siebert K.J. (2009).Process for the production of tilapia retorted skin gelatin hydrolysates with optimized antioxidative properties. Proc. Biochem. 44: 1152-1157.

\section{تدعيم النودلز بالكولاجين المتحلل كفذاء وظيفى أميرة محمد عبد الخالق عبد السلام ـمحمود فرحات سيد عواد قدوس معهد بحوث تكنولوجيا الأغذية ـ مركز البحوث الزراعية ـ الجيزة ـ مصر ملخص}

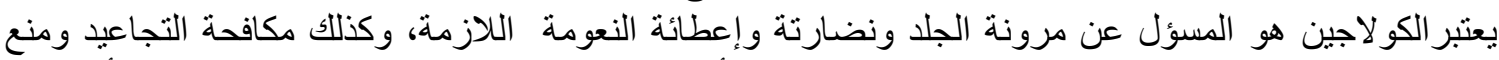

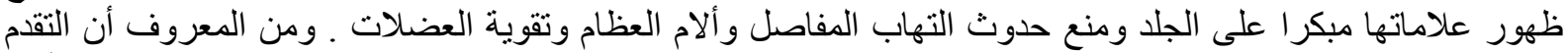

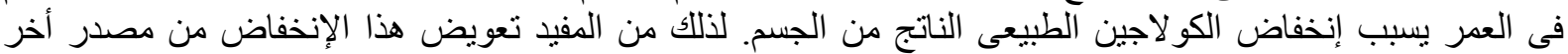

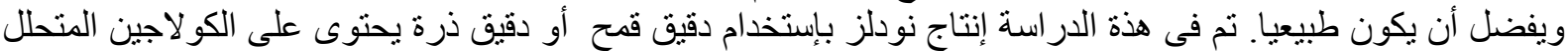

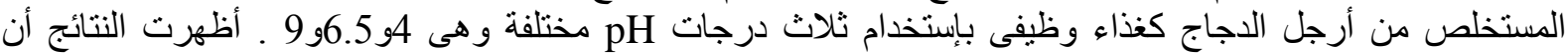

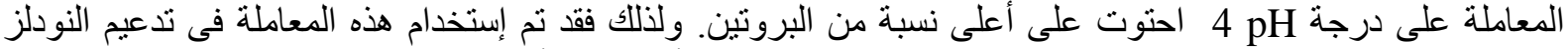

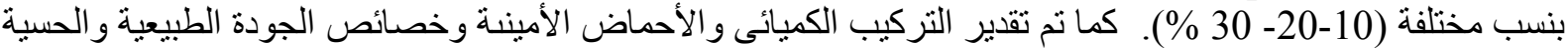

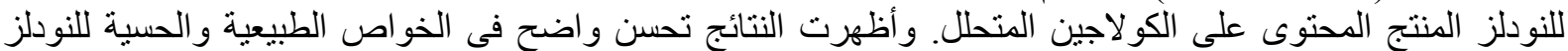

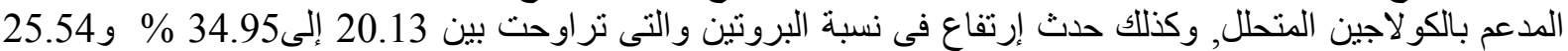

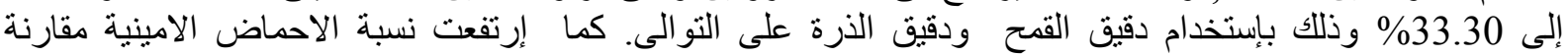

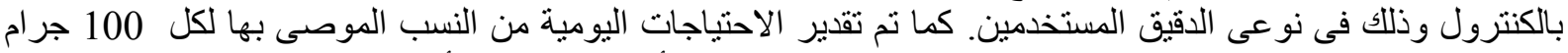

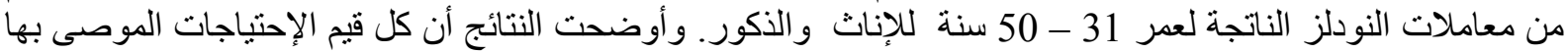

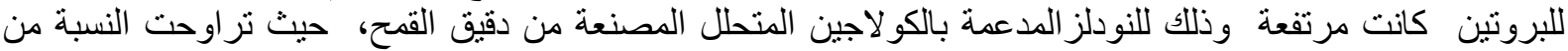

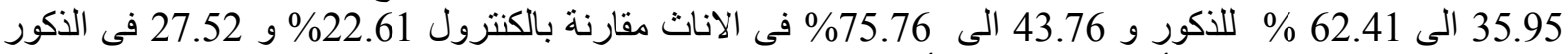

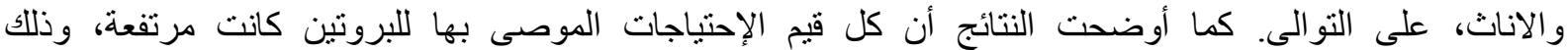

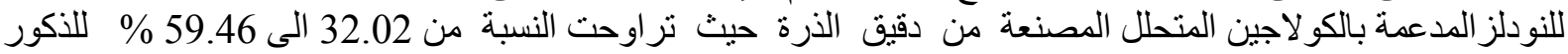

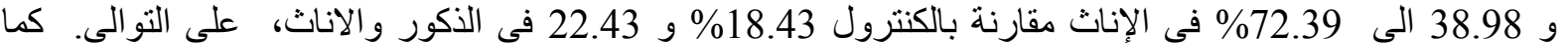

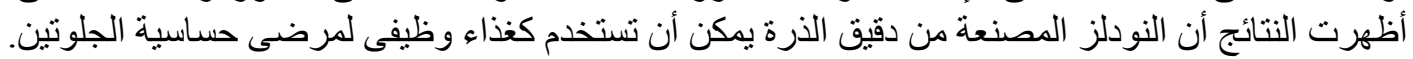

